\title{
Mountain States Census Division
}

National Cancer Institute

\section{Source}

National Cancer Institute. Mountain States Census Division. NCI Thesaurus. Code C76345.

A census division of the United States consisting of Arizona, Colorado, Idaho, Montana, Nevada, New Mexico, Utah, and Wyoming. 